\title{
PENGEMBANGAN APLIKASI M-COMMERCE PADA TOKO OPTIK MENGGUNAKAN ANDROID STUDIO
}

\author{
Egy Muhammad Rianof ${ }^{1}$, Bambang P. Adhi², Z.E. Ferdi F. Putra ${ }^{3}$
}

${ }^{1}$ Mahasiswa Prodi PendidikanTeknik Informatika dan Komputer, Teknik Elektro, FT - UNJ

${ }^{2,3}$ Dosen Prodi Pendidikan Teknik Informatika dan Komputer, Teknik Elektro, FT - UNJ

1egy.rianof@gmail.com, ${ }^{2}$ bambangpadhi@unj.ac.id, ${ }^{3}$ ferdifauzan@unj.ac.id

\begin{abstract}
Abstrak
Seiring dengan perkembangan teknologi informasi dan komunikasi, membuka peluang untuk melakukan transaksi bisnis melalui handphone. Kegiatan bisnis melalui handphone inilah yang kemudian disebut dengan m-commerce. Tujuan dari penelitian ini adalah terciptanya aplikasi Android m-commerce yang memberikan kemudahan bagi calon customer kacamata dalam proses pembelian kacamata. Penelitian ini menggunakan metode Scrum yang memiliki 3 tahapan dalam pelaksanaannya yaitu: tahap Pre-game, Development, dan Post-game. Pada tahap Pregame, segala perencanaan sebelum memulai proses pengembangan sistem dalam bentuk Product Backlog yang membutuhkan persetujuan dari klien, task list, dan jadwal pengerjaan sistemnya. Pada tahap Development, dilakukan pengembangan produk secara iterasi mulai dari perancangan, desain, membuat kode, dan pengujian sistem sesuai jumlah sprint. Pada tahap Post-game, produk sudah dapat dikatakan selesai dikembangkan. Hasil dari penelitian ini adalah customer dapat langsung mengunggah foto resep dari dokter dihalaman pemesanan atau bisa langsung menuliskan informasi lensa untuk mata kanan dan mata kiri yang dibutuhkan customer dan status produk yang sudah dipesan bisa langsung dilihat statusnya oleh customer di menu order status.
\end{abstract}

Kata kunci : m-commerce, Teknologi, Android

\section{Pendahuluan}

Berjualan menggunakan smartphone disebut dengan m-commerce. M-commerce memiliki karakteristik tertentu yang membedakan mcommerce dengan e-commerce. Karakteristik mcommerce adalah ubiquity, immediacy, localization, pro-active functionality, instant connectivity, dan simple authentication procedure. Ubiquity berarti bahwa pengguna dapat mengakses layanan dan melakukan transaksi di mana pun mereka berada. Immediacy berarti bahwa pengguna dapat memperoleh layanan real-time kapan pun mereka mau. Localization adalah fitur yang muncul karena adanya penggunaan teknologi GPS (Global Positioning System) yang memungkinkan pengguna mendapatkan layanan di tempat di mana dia tinggal. Pro-active functionality adalah kemungkinan pengguna mendapatkan informasi yang relevan pada waktu yang tepat dan tempat yang tepat sehingga pengguna tidak akan melewatkan informasi yang berpotensi berharga. Instant connectivity berarti pengguna akan selalu mudah terhubung ke jaringan. Dan yang terakhir, simple authentication procedure berarti setiap pengguna akan selalu diidentifikasi melalui kartu SIM (Subscriber Identity Module) yang ada di perangkat seluler pengguna (Priyambodo dkk, 2012:72).

Berbeda dengan m-commerce atau toko online berbasis smartphone, toko konvensional merupakan kegiatan atau transaksi jual-beli yang dilakukan secara langsung, bertatap muka antara penjual dengan pembeli. Toko Konvensional memiliki kekurangan, yaitu lingkup pemasarannya terbatas, jika ingin memperluas lingkup pemasaran, maka harus membuka cabang di berbagai daerah, dan juga membutuhkan modal yang cukup besar karena toko konvensional memerlukan tempat yang strategis untuk memasarkan produknya.

Toko optik yang masih menerapkan metode pemasarannya hanya secara konvensional memiliki kekurangan. Selain dari biaya yang dikeluarkan lebih besar, konsumen dari toko optik itu sendiri hanya sebatas sekitar lingkup dari toko optik itu berada.

Setelah selesai tanya-jawab kepada pihak Calon pemilik toko optik, informasi yang didapatkan adalah toko optik yang didirikan akan diberi nama Wise Optik, pemilik toko optik akan menjual berbagai frame kacamata dan lensa seperti: lensa tunggal, bifokal, dan progresif. Calon pemilik toko optik ingin memasarkan produknya tidak hanya secara konvensional, tetapi juga secara online ini dikarenakan beliau ingin menargetkan konsumen dari kalangan anak muda yang dimana anak muda di era modern ini lebih cenderung membeli barang secara praktis yaitu secara online. Maka dari itu aktifitas jual-beli akan semakin membaik dan menarik jika dilakukan secara online di era modern ini, termasuk toko optik. Didukung dengan smartphone maka dapat mempermudah konsumen untuk membeli kacamata. 
Mengingat pentingnya hal tersebut, maka dibuatlah sebuah penelitian dengan judul "Pengembangan Aplikasi M-commerce Pada Toko Optik Menggunakan Android Studio".

\section{Dasar Teori}

\subsection{M-Commerce}

Merupakan subset dari e-Commerce didefinisikan sebagai semua kegiatan yang berhubungan dengan transaksi komersial melalui jaringan komunikasi dengan wireless devices atau perangkat mobile. Pada umumnya, perangkat enduser yang digunakan pada proses $\mathrm{m}$-Commerce antara lain Handphone, Smartphone, Personal Digital Assistant (PDA). M-Commerce dapat meningkatkan produktivitas dengan data berkecepatan tinggi dan sistem mobile yang hemat biaya dan pelanggan dapat menggunakan aplikasi m-commerce pada tempat dan situasi yang berbeda. (Carundeng dkk, 2013:1)

\subsection{Sistem Operasi Mobile}

Sistem operasi adalah sebuah program yang bertindak sebagai perantara (interface) antara pemakai (user) dengan perangkat keras (hardware). (Setiawan, 2017:8).

Sistem operasi pada mobilephone memiliki beberapa jenis, yaitu : (Hartoko, 2013)
1. Symbian
2. $\mathrm{iOS}$
3. Android
4. Blackberry
5. Windows Phone

\subsection{Android Studio}

Android Studio adalah Integrated Development Environment (IDE) pemrograman Android resmi dari Google yang dikembangkan oleh IntelliJ. Android Studio memiliki banyak fitur yang memudahkan para pembuat program terutama programmer level dasar. Selain memiliki banyak fitur, Android Studio juga memiliki banyak library yang sudah siap untuk digunakan. Walaupun Android Studio lebih banyak menghabiskan memory, tetapi hal ini dapat ditutupi dengan kelebihan-kelebihan yang dimiliki oleh Android Studio itu sendiri.

\subsection{Kualitas Software}

Kualitas perangkat lunak dapat dinilai melalui ukuran-ukuran dan metode-metode tertentu, serta melalui pengujian-pengujian software. Beberapa model penilaian kualitas software menurut (Pressman, 2010), yaitu:

1. Garvin's Quality Dimensions

2. McCall's Quality Factors

3. ISO 9126 Quality Factors

\section{Metodologi}

Metode pengembangan sistem ini menggunakan Research and Development dan metode pengembangan produknya, menerapkan Agile yaitu Scrum. Metode Scrum ini menggunakan gabungan iterasi dan incremental. Pengembangan dalam Scrum menggunakan sprints yang berulang atau iterasi dan menghasilkan incremental di akhir sprint. Dalam proses pengembangan, metode ini akan disesuaikan dengan peneliti yang tidak menggunakan tim pengembang.

\subsection{Prosedur Pengembangan}

Proses dalam Scrum menggunakan 3 fase, yaitu fase pre-game, fase development, dan fase post-game. (Abrahamsson, et.al, 2003)

\subsection{Pengumpulan Data}

Pengambilan data secara tertulis dengan menyediakan pertanyaan kepada responden dari pihak customer. Kuesioner terkait fungsional dan fitur yang akan diimplementasikan ke sistem. Kuesioner akan menggunakan skala Guttman. Tujuan skala ini adalah untuk memperoleh ukuran gabungan yang bersifat unidimensional (hanya mengukur satu dimensi saja) seperti ya-tidak.

\subsection{Analisis Data}

Peneliti akan menggunakan analisis produk Black-box testing atau behavioral testing. Pengujian ini berfokus pada kebutuhan fungsional dari sistem. Jadi pengujian akan berhasil jika fungsi-fungsi yang diuji berjalan sesuai harapan dan rencana.

Black-box testing bertujuan untuk menemukan kesalahan pada fungsi sistem, tampilan, struktur data, akses basis data, performa, dan penanganan kesalahan. (Pressman, 2010)

\section{Hasil dan Analisis}

Hasil dari penelitian ini berupa aplikasi $m$ commerce pada toko optik di sistem operasi mobile Android.

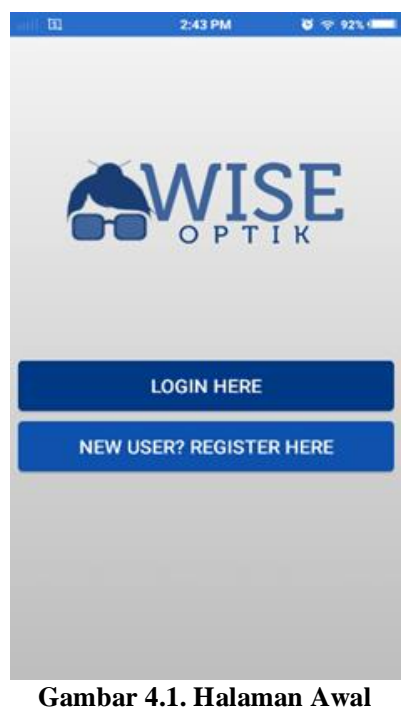



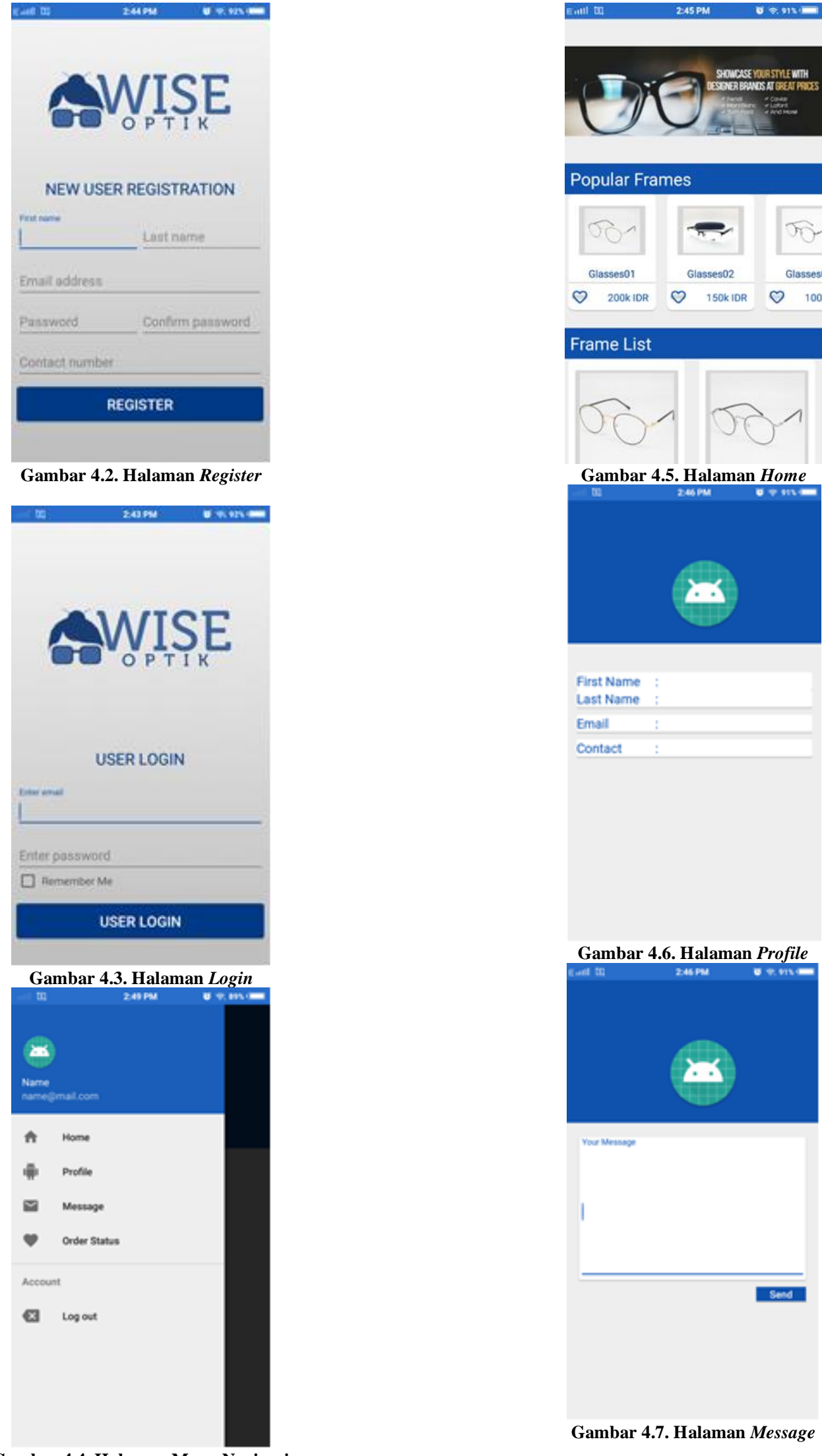

\section{Frame List}

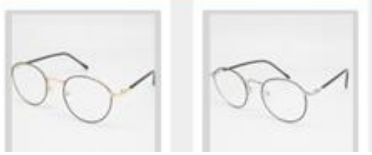

Gambar 4.5. Halaman Home
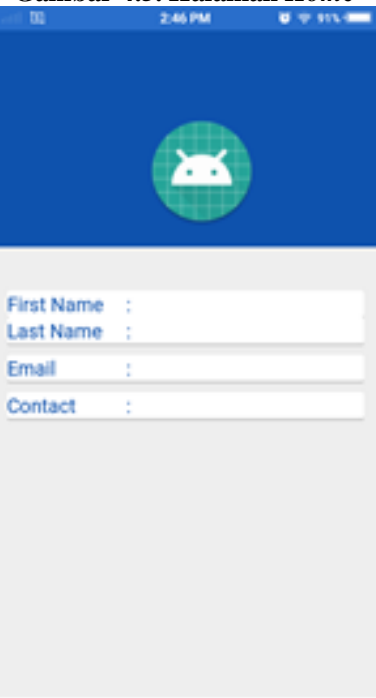

Gambar 4.6. Halaman Profile
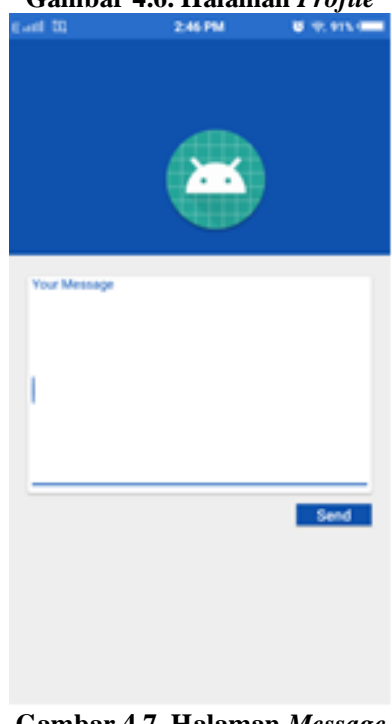

Gambar 4.4. Halaman Menu Navigasi 

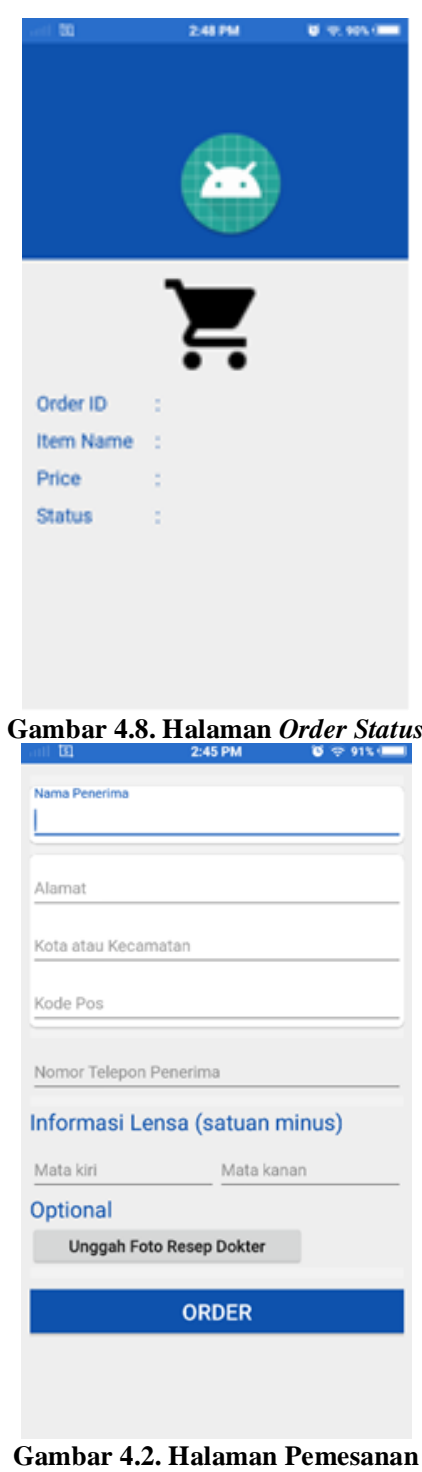

\subsection{Hasil Uji Coba}

Pengujian fungsional dilakukan setelah melaksanakan sprint, jadi sebanyak dua kali. Responden berasal dari mahasiswa Universitas Negeri Jakarta yang berjumlah dua orang bernama Muhammad Nur Afandy dan Reno Biastomo dengan pengguna administrator berjumlah satu orang yaitu pemilik toko Optik yang bernama Bapak Nofrizal.

Seluruh hasil pengujian dapat berjalan dengan baik tanpa adanya hambatan. Sehingga dapat dikatakan aplikasi Android sudah dapat berjalan dengan baik dan secara fungsional sudah sesuai dengan daftar product backlog yang direncanakan dan disepakati oleh pemilik produk.

\section{Kesimpulan dan Saran}

Berdasarkan pembahasan kegiatan pengembangan aplikasi Android m-commerce pada toko optik, maka dapat diambil kesimpulan bahwa pengembangan sistem ini menggunakan metode scrum dengan tahapan mulai dari perancangan pada tahap Pre-game seperti penentuan Product Backlog, task list dan jadwal pengerjaan sistemnya. Pada tahap development dilakukan pengembangan produk secara iterasi mulai dari perancangan, desain, membuat kode dan pengujian sistem sesuai jumlah sprint. Di tahap post-game produk sudah dapat dikatakan selesai dikembangkan.

Berdasarkan hasil pengujian fungsional, aplikasi yang dikembangkan sudah dapat digunakan karena telah memenuhi seluruh kebutuhan yang diminta klien. Metode pengembangan yang diterapkan pada penelitian ini cocok digunakan untuk pengembangan aplikasi yang memiliki kebutuhan yang dinamis dan pengerjaan waktu yang terstruktur serta relatif singkat.

Penelitian ini menghasilkan aplikasi m-commerce berbasis Android yang membuat customer dapat langsung mengunggah foto resep dari dokter dihalaman pemesanan atau bisa langsung menuliskan informasi lensa untuk mata kanan dan mata kiri yang dibutuhkan customer dan status produk yang sudah dipesan bisa langsung dilihat statusnya oleh customer di menu order status.

\section{Daftar Pustaka:}

Abrahamsson, P., Warsta, J., Siponen, M. T., \& Ronkainen, J. (2003). New directions on agile methods: a comparative analysis. Software Engineering, 2003. Proceedings. 25th International Conference.

Carundeng, M, J., Kaunang, S. T., Lumenta, A. S., \& Rumagit, A. M. (2013). Pembuatan Prototipe mCommerce, Pemesanan Tiket Angkutan Antar Kota Berbasis Wireless Application Protocol. Jurnal Teknik Elektro dan Komputer.

Hartoko, Alfa. (2011). Kupas Tuntas Online dengan Ponsel. Jakarta: PT. Elex Media Komputindo.

Pressman, R, S. (2010). Software Engineering: A Practitioner's Approach. America, McGraw Hill, Ed ke-7.

Studio, Android. (2018). "Mengenal Android Studio".

https://developer.android.com/studio/intro/?hl= id. Diakses 27 Juli 2018.

Sugiyono. 2011. Metode Penelitian Kuantitatif, Kualitatif dan R\&D. Bandung: Alfabet 